tion of the new system, and after it. The same sort of difficulty now exists in comparing observations made before and after the introduction of the Gregorian calendar; but in this case the discontinuity amounts to ten or eleven days, and cannot escape notice, while the discontinuity involved in the proposed system would be only twelve hours, and might easily be overlooked with most damaging consequences. This objection is undoubtedly valid and weighty. The other objections urged, as to changes needed in the ephemerides, really amount to very little. At present, one has to stop a moment to consider whether he is acting as a civilian or an astronomer when he opens the Ephemeris to look out data ; and it is quite immaterial as regards the numbers given for noon, for instance, whether noon is called $0 \mathrm{~h}$. or $12 \mathrm{~h}$. As to the changes in the printing of the Ephemeris, they would involve a little extra work the first year, but nothing of any consequence.

Per contra, a considerable majority of the astronomers consulted by Commodore Franklin were of opinion that the advantage gained by abolishing the distinction between civil and astronomical reckoning would fully compensate for the admitted annoyance consequent upon the change. The number of people inconvenienced by the change would be very small, and they would be persons abundantly able to guard against mistakes such as others would be likely to make. On the other hand, the present system leads to confusion in the case of all neophytes in astronomical work : indeed, pretty good astronomers are sometimes caught napping when they look into the almanac for forenoon data; and in publishing observations it is often necessary, and always wise, to state whether civil or astronomical reckoning is used. Of course, the change in itself considered is of very little importance; but it does seem rather unfortunate that the recommendations of the Washington conference should fail, to begin with, at the Washington observatory, and the effect will undoubtedly be to postpone the acceptance of the whole system of proposed reforms.
THE SCIENTIFIC RESULTS OF THE LADY FRANKLIN BAY EXPEDITION.1

THE general interest in the scientific work of most polar expeditions has been seriously affected by the long delay which necessarily occurs in the publication of the records and results. With the permission and concurrence of Gen. W. B. Hazen, chief signal-officer, I take pleasure in giving, as far as I can at present, a brief summary of some of the scientific results of the Lady Franklin Bay expedition.

Hourly magnetic declination observations for thirty-two days on which they were made previous to July 1, 1882, were reduced at Fort Conger. The mean declination thus obtained was $100^{\circ} 12^{\prime}$ west, being $1^{\circ} 32^{\prime}$ less than the result deduced from the observations of the English expedition of 1875-76. The maximum easterly deflection occurred at 2 A.M., local time ( 7 A.M., Gottingen mean time), and the maximum westerly deflection at 12 м. A primary maximum at 4 P.M., most probably was due to disturbances. 'These deflections are from one to two hours later than those obtained from the observations of Lieuts. Archer and Fulford, R.N., in $1875-76$; but it is possible that the observations for the complete year, which are now in the hands of Assistant Charles Schott of the U.S. coast and geodetic survey for reduction, may give other results. The hours, however, agree with those determined for Van Rensselaer harbor by Mr. Schott, in the discussion of Kane's observations. 'The absolute range of the English observations was $8^{\circ}$; and the greatest daily change, $5^{\circ}$ 9.4'. From 8.35 A.м. (Gottingen mean time), Nov. 16, 1883, to 10.30 P.M., Nov. 18, the absolute range as observed was $20^{\circ} 28.2^{\prime}$, - from $113^{\circ} 19.8^{\prime}$ west, to $92^{\circ} 51.6^{\prime}$ west. These times and figures are given as of more than common interest in connection with the great magnetic storm of November, 1883. The changes at Conger were much greater, it will be observed, than at Godthaab, Greenland, where, Paulsen says, on Nov. 17, 1883, from 2 A.M. until noon, the declination had varied $4^{\circ} 44^{\prime}$ to the east, and later about $5^{\circ}$ to the west; so that the variations for the day reached $9.5^{\circ}$.

The following table of monthly means has

1 The accompanying picture represents Fort Conger as it was photographed by Sergeant George W. Rice, in March, 1882, the print from which it was taken being one of the few that were brought safely home by the Greely party. 'The high ground at the north-west of the station is seen at the left. The picture represents the principal building occupied. There were three other small structures, astronomical and magnetic observatories, and an instrument-shelter, the wires seen at the right running to the astronomical observatory. 


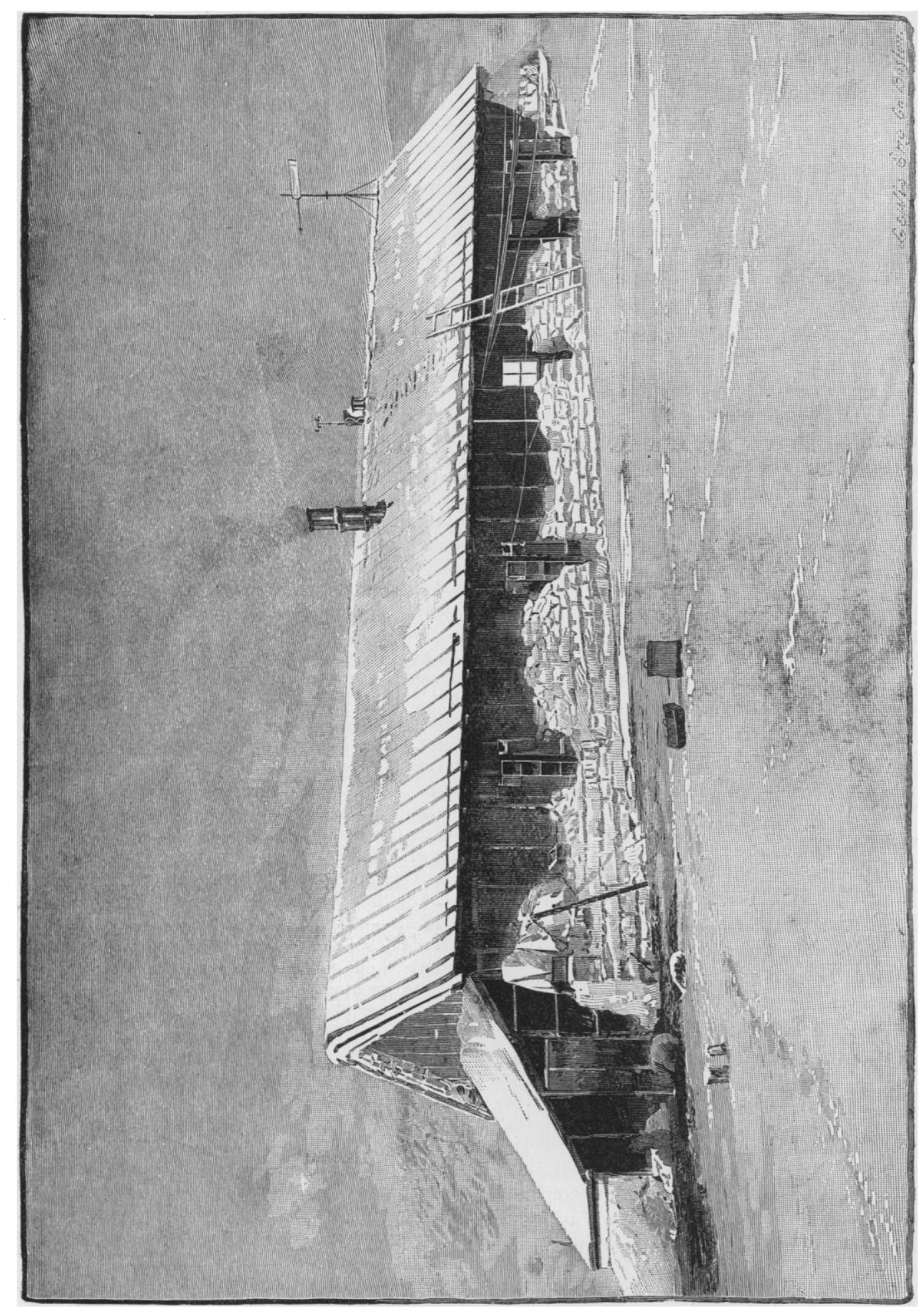

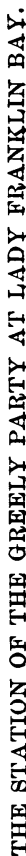


been compiled from three years' observations,1875-76 and 1881-83.

\begin{tabular}{|c|c|c|c|c|c|c|c|c|}
\hline & & & & & & $\begin{array}{c}\text { Barometer } \\
\text { to sea. }\end{array}$ & $\begin{array}{c}\text { Tempera- } \\
\text { ture. }\end{array}$ & $\begin{array}{l}\text { Rainfall, in- } \\
\text { ches (two } \\
\text { years only). }\end{array}$ \\
\hline $\begin{array}{l}\text { January } \\
\text { February } \\
\text { March : } \\
\text { April : } \\
\text { May : } \\
\text { June : } \\
\text { July : } \\
\text { August } \\
\text { September } \\
\text { October. } \\
\text { November } \\
\text { December }\end{array}$ & $\begin{array}{l}\dot{:} \\
\dot{.} \\
\dot{.} \\
\dot{.} \\
\dot{.}\end{array}$ & $\dot{\cdot} \cdot \dot{ } \cdot$ & $\begin{array}{l}\dot{:} \\
\dot{.} \\
\dot{.} \\
\dot{.} \\
\dot{.}\end{array}$ & $\begin{array}{l}\dot{:} \\
\dot{:} \\
\dot{:} \\
\dot{.} \\
\dot{.}\end{array}$ & 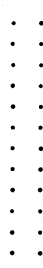 & $\begin{array}{r}29.756 \\
0.779 \\
0.962 \\
30.175 \\
0.021 \\
29.852 \\
0.725 \\
0.787 \\
0.749 \\
0.925 \\
0.971 \\
0.830\end{array}$ & $\begin{array}{r}-38.3^{\circ} \\
-40.1^{\circ} \\
-28.3^{\circ} \\
-13.6^{\circ} \\
+14.1^{\circ} \\
32.7^{\circ} \\
37.1^{\circ} \\
33.8^{\circ} \\
15.8^{\circ} \\
-8.9^{\circ} \\
-23.3^{\circ} \\
-28.1^{\circ}\end{array}$ & $\begin{array}{l}0.42 \\
0.13 \\
0.45 \\
0.17 \\
0.40 \\
0.18 \\
0.66 \\
0.38 \\
0.35 \\
0.24 \\
0.20 \\
0.30\end{array}$ \\
\hline Year. & . & $\theta^{\circ}$ & . & - & . . & 29.878 & $-3.9^{\circ}$ & 3.88 \\
\hline
\end{tabular}

The barometrical observations show atmospheric changes which I believe are common to the region within the arctic circle, north of America at least. The marked maximum pressure in April gives way rapidly to the principal minimum in $\mathrm{July}$; to be followed by a secondary maximum in November, and a less marked minimum in January or February.

The hourly barometric observations are of special interest as tending towards a final solution of the question whether or not the regular diurnal variation observed in lower latitudes also occurs near the poles. Buchan, noting the fact that the range at St. Petersburg and Bosukop is but about .012 of an inch, remarks, "And in still higher latitudes, at that period of the year when there is no alternation of day and night, the diurnal variation probably does not occur."

The first year's observations at Fort Conger satisfied me that such diurnal variation does occur in very high latitudes, and my opinion was confirmed by subsequent observations. Reductions made several months before the station was abandoned, from nearly five hundred days' continuous observation, showed a range of .0099 of an inch. The primary maximum occurs at 5 A.M., Washington mean time (which is 53 minutes slower than local time), followed by the primary minimum at 1 P.M. The secondary maximum and minimum took place at 6 P.M. and midnight respectively. To determine whether the presence or absence of the sun affected the fluctuation, I calculated separately the means of the days of continual darkness and continuous sunlight up to May 1, 1883. The diurnal fluctuation was substantially the same, and the critical hours were identical in the arctic night and in the polar day.

The absolute range of the barometer ob- served was 2.032 inches, - from 31, April 9, 1882 , to 28.968 , Feb. 19,1883 . It is interesting to note that the minimum pressure for the year 1882-83 at Godthaab and in Spitzbergen occurred respectively one day earlier and three days later than at Fort Conger. The barometer at Godthaab touched the unusually low point of 27.89 .

The annual mean temperature $\left(-3.9^{\circ}\right)$ is the lowest on the globe, being $1.4^{\circ}$ below that deduced for Van Rensselaer harbor from Kane's observations. It quite disposes of the theories of a warmer climate as the pole is approached. The maximum mean at Fort Conger agrees with that of other arctic stations in general, occurring in July; and the monthly mean gradually declines to the minimum in February. This month, I think, is generally the coldest at arctic stations; and, when the lowest mean has been noted in January (or occasionally in March), I believe a series of years would change it to February. The lowest monthly mean $\left(-46.5^{\circ}\right)$ for February, 1882, must give way, however, to that at Werchojansk (on the Lena), from which the following means are reported : December, $-50.3^{\circ}$; January, $-56^{\circ}$; and February, $-53^{\circ}$. The highest monthly mean was that of July, $1883,37.2^{\circ}$. The absolute range of temperature was $115.1^{\circ}$, - from $-62.1^{\circ}$, Feb. 3,1882 , to $+53^{\circ}$, June 30 , 1882.

The amount of rain and melted snow was 3.95 inches the first, and 3.82 the second year, irregularly distributed throughout the year. This small amount of precipitation may explain the non-glaciation of the adjacent country. I believe the precipitation in the interior to be less than at Fort Conger.

The wind resultants are as follows: first year, S. $61.4^{\circ}$ E. 7594 miles; second year, S. $67.3^{\circ}$ E. 6437 miles. The wind was more southerly from 2 to 4 P.M., inclusive, than at other hours during the first year, and from 11 A.M. to 2 P.M. the second year.

The mean tidal establishment was determined by me at Fort Conger from two years' observations on a fixed gange, as follows :-

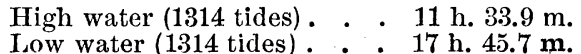

Complete series of high and low waters for two years, with regular hourly readings of the tide for one year at Fort Conger, have been placed in the hands of Mr. Schott. These observations, with supplementary simultaneous readings at Capes Sumner, Beechy, Craycroft, Leebi, and at Repulse harbor, added to Bessel's and Nares' observations, will, I trust, enable 
tidal experts to determine the co-tidal curves for Lincoln Sea, and Robesen and Kennedy channels.

The temperature of the surface sea-water was carefully observed from October, 1882, to June, 1883. The temperature fell steadily from a mean of $29.2^{\circ}$ in October, to $29^{\circ}$ in December, and then rose steadily to $29.4^{\circ}$ in June. The ebbing tide (to the north) was from $0.1^{\circ}$ to $0.2^{\circ}$ colder than the flowing tide, and its mean for December was $28.9^{\circ}$.

The sounding of 133 fathoms and no bottom, midway between Capes May and Britannia, is significant of a different ocean along the north coast of Greenland, from the shallow sea north of Asia, North America, and Grinnell Land.

Forty-eight swings, with accompanying time observations, were made with a pendulum furnished by the U.S. coast and geodetic survey. The observations are now in the hands of Assistant Charles S. Peirce for reduction and comparison. I regret that continued mental and physical weakness have prevented more careful and systematic treatment of these subjects. This summary is now presented, as the immediate future promises no better results from my hands.

A. W. Greely, U.S. army.

\section{FOOTPRINTS IN THE ROCKS OF COLORADO.}

From a few tracks and signs, an Indian is said to have inferred that at noon there had passed by a white man, lame in the left foot, blind in the right eye, dressed in gray, and with a double-barrelled gun and a black dog. With no attempt to rival the aborigines, nor to name and classify, it is interesting to notice some features of the footprints on four slabs from St. Vrain Creek, Col., - the only vestiges of animal life thus far reported from the immense beds of triassic sandstones in the eastern Rocky Mountains. Three of the slabs are in the museum of Iowa college, Grinnell, Io.: the other, No. 2, has been sent to the national museum.

Slab No. 1, represented in the figure, with two of the tracks on a larger scale, is somewhat like the rare horseshoe forms found in Europe and in the Connecticut valley, in rocks of the same age. No hoofed animal is supposed to have existed at so early a period. The shape has been attributed to a membrane beneath claws, in this case a firm, flat pad, if that be the explanation, and semicircular within as well as exteriorly. In the three forward tracks, the fore and hind feet coincided, making one impression. In four of the remaining tracks, the smaller fore-feet show a crescent that coalesces with that of the hindfoot. There is a rough, broken, irregular bulging of the rock in and behind the hollow of the foot, dying away backward into the surface. The great amount of this would suggest that the animal was ascending a wet slope.

The appearance of slab No. 3 is so like No. 2 that they were probably one continuous series. As seen in the figure, the larger impression of the hind-foot mostly touches, and once or twice somewhat overlaps, that of the fore-foot, which is evidently such because its position varies relatively to the former. It has a wide angle from the line of progression. In the last (uppermost) left feet, the fore-foot repeats its print, though at first glance it looks like a jointed toe. All the impressions are simple ovals (ellipses), deepest in the centre; and several, as in the larger separate figure, have a shallow ear-shaped impression on the inner forward border, which, in two, shows slight lengthwise wrinkles. The left-side tracks are less perfect, as if the right feet pressed on a lower, wetter part of the ancient beach.

In No. 3 there was an inch space between the heels in passing each other; in No. 1, little

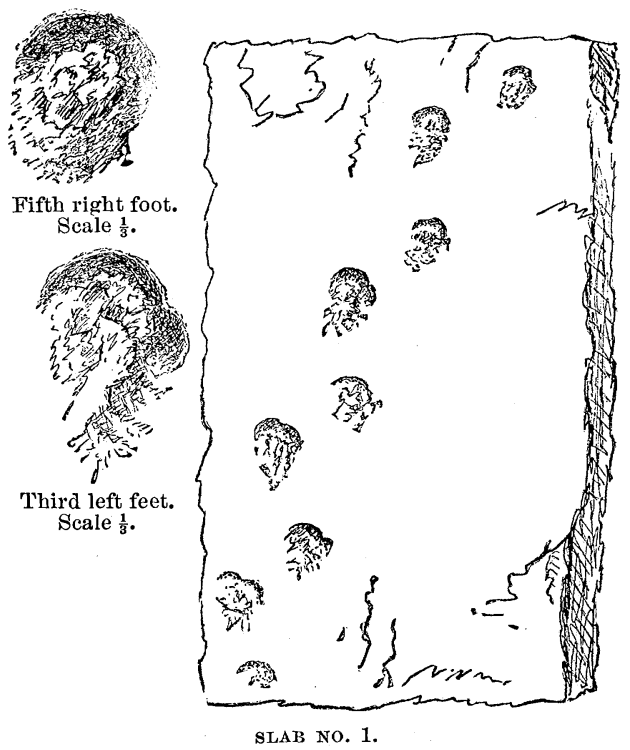

Average stride, $8 \frac{1}{2}$ inches; width of trackway, $4 \frac{1}{4}$ inches. Scale, 1-12.

or none. The animals must therefore have had an erect habit, not the dragging movement, with horizontally extended legs, of ordinary reptiles, if reptiles they were. 